\title{
E-BOOKS MARKET IN POLAND. A FEW GOOD MEN'S PASSION IN A NON-READING SOCIETY
}

\section{Barbara Chmielewska}

University of Warsaw Library, Warsaw Poland; e-mail:b.chmielewska@uw.edu.pl

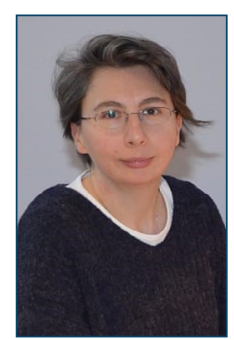

Chmielewska Barbara, mgr, head of fund acquisition department

ORCID: 0000-0001-9700-0709 e-mail: b.chmielewska@uw.edu.pl

\begin{abstract}
The article's aim is to give an overview of the e-books market in Poland, including some issues from the history and perspectives of its future development; to reveal the role of authors and bloggers in popularizing e-books and e-reading; to elucidate how preferences of Poles in e-books reading devices and their attitude towards electronic reading were changing; to analyse problems that publishers and e-books sellers face. The article is based on social interrogation data, works of researchers and Polish book market analysts.
\end{abstract}

The period between 2009-2018 demonstrate the following main characteristics of the market: rapid changes in technology, necessary for creating e-books; changing habits of the Polish readers, the lack of systematized approach to e-books as new media and economic barriers such as rather high VAT rate for digital publications. The paper underlines also the role of individuals and their initiatives in shaping the broadband culture. The basic conclusion of the work is as follows: Polish e-books market is still at the stage of forming its main segments. This work novelty and theoretical significance is in exposing and characterizing tendencies of e-books market evolution in Poland.

Practical significance of the work is in acknowledging the necessity of attracting publishers, librarians and researchers to solving problems of creation in the country a constantly renovated database of electronic editions, its accessibility by Pole users.

Keywords: e-books, electronic reading, electronic devices for reading, publishing houses, shops, market, culture, Poland

Citation: Chmielewska B. E-books market in Poland. A Few good men's passion in a non-reading society. Bibliosphere. 2020. № 1. P. 93-101. DOI: 10.20913/1815-3186-2020-1-93-101. 


\section{РЫНОК ЭЛЕКТРОННЫХ КНИГ В ПОЛЬШЕ. УВЛЕЧЕНИЯ НЕМНОГИХ ХОРОШИХ ЛЮДЕЙ В НЕЧИТАЮЩЕМ ОБЩЕСТВЕ}

\section{Барбара Хмелевска}

Университетская библиотека в Варшаве, Варшава, Польша;

e-mail:b.chmielewska@uw.edu.pl

Хмелевска Барбара, магистр, заведующий отделом комплектования фондов; ORCID: 0000-0001-9700-0709 e-mail:b.chmielewska@uw.edu.pl

Received 20.11.2019

Revised 24.02.2020

Accepted 27.02.2020
Аннотация. Цель статьи - дать обзор рынка электронных книг в Польше. Освещена история его формирования, намечены перспективы его будущего развития; раскрывается роль писателей и блогеров в популяризации электронных книг; показано, как менялось отношение поляков к электронному чтению и их предпочтения при выборе устройств для чтения электронных книг; анализируются проблемы, с которыми сталкиваются современные польские издатели и продавцы электронных книг. В статье использованы данные социологических опросов, аналитические отчеты экспертов польского книжного рынка, научные исследования.

В 2009-2018 гг. проявились основные характеристики формирующегося в Польше электронного книжного рынка: быстрые изменения технологий, необходимые для создания электронных книг; меняющиеся читательские практики; отсутствие систематизированного подхода к электронным книгам как новым медиа; наличие экономических барьеров, таких как высокая ставка НДС на цифровые публикации. В статье раскрывается роль отдельных людей и их инициатив в формировании современной медиакультуры и практик цифрового чтения. Основной вывод работы: польский рынок электронных книг все еще находится в стадии формирования своих главных сегментов. Новизна и теоретическая значимость работы заключается в выявлении и характеристике тенденций развития рынка электронных книг в Польше. Практическая значимость работы заключается в признании необходимости привлечения издателей, библиотекарей и исследователей к решению задач создания в стране постоянно обновлямой базы данных электронных изданий, ее доступности для всех пользователей.

Ключевые слова: электронные книги, электронное чтение, электронные устройства для чтения, издательства, магазины, рынок, культура, читательские практики, Польша

Для цитирования: Хмелевска Б. Рынок электронных книг в Польше. Увлечения немногих хороших людей в нечитающем обществе // Библиосфера. 2020. № 1. С. 93-101. DOI: 10.20913/1815-3186-2020-1-93-101.

\section{Introduction}

„They are everywhere - in the subway, in buses, in parks, at universities and in the offices. They - we mean e-readers with their reading devices - readers, tablets, smartphones. How many are they in Poland? Nobody has researched it so far" (Drózd, 2014). This was the beginning of "Czytnikoliczenie” ", a national survey organized by an internet book store Virtualo together with Allegro - a popular Polish e-commerce platform, a Polish equivalent of Ebay. „Czytnikoliczenie" was a result of the fact that e-reading had become more and more popular, had been noticed as a phenomenon and ready to be systhematized and studied.

E-readers as devices appeared in the golbal distriubution in the 90-ties of 20th century. At that time SONY was the leader of the market. However, the real breakthrough and revolution in the world of e-readers and e-books came together with the introducion of the product of Amazon - the KINDLE. These are common facts. We mention them here to underline the general and well known characteristic of the modern world: a rapid change. Today, only ten years later, few would say that SONY is a leading brand, and KINDLE is being used by the vast majority of e-readers. 


\section{E-books in Poland: the beginning of the} history

The possibility to order KINDLE by mail order sales was also for the Polish e-books market ${ }^{2}$ a begining of a new chapter in the history of e-reading. It is impossible to talk about e-books and not mentioning the devices to display them ${ }^{3}$. Polish customers go tinto ruptures over KINDLE and to the present day this device is the one that they buy most often.

Nearly at the same time as KINDLE was introduced to the new areas of demand and sale two other significant situations occured in Poland and it is worth mentioning them at the very beginning for they are not only important in the history of e-reading, but they illustrate as well the general tendencies of the Polish book market. The first of these events was the publication of a book entitled rather provocatively The death of the book. No future book in 2008 (Gołębiewski, 2008). The author, Łukasz Gołębiewski, a journalist and book market analityst, made a perfect use of the moment of transformation of the analogue print book culture into the digital print book culture ${ }^{4}$. His book gives a brief but profound insight into many crucial issues, pose questions about the future of the book and reading as such. In the following years (2010) Gołębiewski published Eksiażka/book. Broadband culture (Gołębiewski, 2009) and finally (2012) another book with another catchy title Where has the reader gone?

When we say "Market of electronic books in Poland" we mean both books in retail trade, available for each client, but also books in packages, offered for purchase mainly to libraries and institutions of science and culture by individual publishers (Polish and foreign) and the so-called aggregators dealing with the sale of e-content, such as EBSCO or ProQuest. This is a very contractual division, because it is impossible to draw an exact line between who sells what kind of content. At the very beginning, it could be determined with great accuracy, but at the moment this border is very blurred, especially when it comes to books in Polish. One of the most important players on the ebooks market is the PWN publishing group with its IBUK Libra ebooks sales platform. IBUK Libra's offer is addressed to both individual and institutional customers. Just like the offer of the second most important player the Virtualo online bookstore. However, in this article I would like to focus primarily on the retail sale of electronic books or, in other words, on the individual recipient, the statistical e-reader, their behaviour and their environment.

An electronic book is not suitable for reading "right away". Due to its immaterial form, it requires a device such as a reader tablet, computer screen or smartphone to display it. This is one of its biggest drawbacks and arguments put forward by ardent supporters of traditional books. The lack of a reading device is the reason for excluding a certain group of potential recipients. Of course, in today's world this is a minority, because more people have access to a smartphone than to a toothbrush.

Let us recall that in mid-March 2012, the world was surprised with the news that Brittanica was resigning from publishing a paper version of the Encyclopaedia, which had been published continuously for 244 years. In the history of the printed book, this was undoubtedly a breakthrough event. The era of electronic books has begun for good. Of course, much earlier there were voices that were both joy- and fearful that a printed book is forgotten, dying and will be replaced by an electronic book on more or less popular e-readers (https://www.the guardian.com/books/2012/mar/13/encyclopedia-britannica-haltsprint-publication).
(Gołębiewski, 2012). The „trilogy” of Łukasz Gołębiewski is a splendid example of a mechanism, very popular in a common access to information, where thanks to the Internet the observers and creators of culture draw our attention to specific cultural phenomena much more early than scientists and scholars. They also, in many cases, evaluate and interprete those phenomena more accurately.

The second event, which was a kind of a milestone in the history of the e-book market in Poland, was the appearance of the blog "Świat Czytników" (The world...). The author - Robert Drózd - fascinated by the KINDLE that he acquired in 2010, began to share his fascination with others and for this purpose he founded a blog. The blog still exists today, and the author, still very much "in love with e-reading", runs it with unwavering passion (The world...), informing his readers about new devices, comparing their functionality, collecting tips, and following all e-book promotions ${ }^{5}$. On his blog there are about 20 articles a month. "There are no reprints from foreign websites, the information is to be practical and focused on the reader from Poland. Swiat czytników is visited by more than 100,000 people a month and this is a place that has a real impact on the Polish e-book market. Over the four years of the blog's existence we have supported various positive changes - increasing the e-book's offer, removal of DRM by Polish bookstores, publishing magazines in reader formats. As part of the blog, I cooperate with many companies, such as e-bookstores, distributors of readers, etc. I also participate in partner programs. However, the service remains independent and is not associated with any manufacturer" (Drózd, 2014). The example of both Gołębiewski and Drózd shows that the passion of one man can have an effective impact on the shape and functioning of the subject of their interest in culture.

\section{Reading in Poland}

It is obvious that everything related to e-books, e-book readers, i. e. simply e-reading, fits into the context of reading in Poland, and further into a broad cultural context. We will try to describe briefly the state of reading in Poland. "Poles have never read much, this is the sad truth" - so we read in the beginning of the third book by tukasz Gołębiewski (Gołębiewski, 2008), mentioned above. His description of the history of reading in Poland is short and accurate. In the last years of the 20th century, after the fall of communism in Poland, with the

This is how the author himself advertises the blog: "You will read it here: what e-readers and e-readin devices are all about; about books to readers - where to get them from, how to buy them, how to convert them from other formats, where to buy legal books; about using Kindle - tricks, hints, tips; about buying Kindle and other e-readers what model to choose, and whether e-reader is actually for you; about the e-readers market - tests and news, heavily filtered in terms of usefulness; about promotions on e-books in Polish bookstores". 
abolition of censorship and paper limits, the fashion for books collected during the regime as a kind of protest against communist power (Gołębiewski, 2008) also disappeared. The short-term increase in readership at the beginning of the 21 st century ended in the middle of the first decade and has since then remained at a similar, low level. This is what the annual readership research conducted by the National Library shows (Koryś et al., 2018). Poles read very little, only $38 \%$ of the respondents read one book a year. And only $9 \%$ read more than 4 books a year. This situation is not improving despite the actions promoting reading and supporting libraries ${ }^{6}$. Considering the constantly growing popularity of book fairs and various types of book selling events, meetings with authors, the low level of readership in comparison with the crowds visiting the fairs seems paradoxical ${ }^{7}$. If we add to this the popularity of book discounts and the fact that e-books - the subject of our article - can often be purchased at a very low price, as well as the e-reader device itself, we do not see at first glance what could be the ground for such poor reading achievements as those reported by the National Library. Perhaps, one of the reasons is that Polish society, with its undoubtedly difficult history including wars, partitions and occupation, before it managed to develop good mass reading habits in a free country, was suddenly dragged into the whirlwind of technological changes and has simply not yet found itself in it.

\section{Book and bookshop market}

After we learned briefly what the reading situation in Poland looks like, let's take a look at the situation on the book and bookshop market. This year, in Poland, Nielsen started its activity by launching a project called BookScan Polska ${ }^{8}$. The analysis of the data collected in this project shows that "the book market in Poland is large, but very fragmented, moreover, poorly categorized and described" 9 (Mendruń, 2018).

Nielsen's diagnosis is to the point. Indeed, no serious publishing house dealing with the book market is involved in a systematic and properly located description of the reality of e-reading. It is enough to

\footnotetext{
6 The programmes are: „Cała Polska czyta dzieciom”, „Czytanie Narodowe", and others lead by the National Library of Poland (https:// www.bn.org.pl/dla-bibliotekarzy/programy-mkidn).

According to data from "Book market in Poland 2017. Trade fairs, institutions, media", the 10 most important trade fair events throughout the year were visited by about 400 thousand visitors.

Rynek-ksiazki.pl. URL: http://rynek-ksiazki.pl/czasopisma/ rynek-ksiazki-po-polsku/ (accessed 12.06.2019).

On 12 October, a text presenting the results of the Bookscan Polska project carried out by Nielsen in July 2018 was published. The project lasted three months and in addition to describing the main characteristics of the Polish book market, it also posed important questions, including what research sample is needed to reliably assess book sales.
}

mention here the fact that although electronic books have been discussed for several years (let's remember that one of the biggest players on the ebooks market - Virtualo - has existed on the market since 2008 , i. e. a year earlier than the "KINDLE revolution"), few specialist publications from the book market, did notice the existence of books in electronic form until 2012 ${ }^{10}$ : "The Polish e-books market is still under construction, although 2011 was a breakthrough year for the development of this market. (...) The e-readers devices market in Poland is already estimated at 100,000 copies, with Kindle readers being the most popular, with a market share of about $50 \%$. The second place is taken by Onyx devices, followed by Pocketbook and Iriver devices. Polish readers also import readers such as Sony, Kobo and Nook that can not be purchased by local vendors. The number of tablets sold is also growing dynamically, while reading using mobile phones is less popular, although every fifth Polish Internet user has a smartphone. In addition to foreign applications, Polish solutions from Woblink, Nexto and Virtualo ${ }^{11}$ are also used, which are related to bookshops where you can buy books. It is estimated that in 2011 the sales of e-books amounted to 9-11 million zlotys (Gołębiewski, Waszczyk, 2012). Since then, "Rynek książki w Polsce", a magazine published by "Biblioteka Analiz"12 devotes every year a bit of attention to electronic publications. The yearbook of the National Library "Ruch Wydawniczy w Liczbach" remains silent in matter of e-books' ${ }^{13}$ (Dawidowicz-Chymkowska, 2018).

At the moment, and we are in 2018, it would seem that the phenomenon of e-books is so well established in reading culture in general that it would be appropriate to devote a separate category to it in specialist publications. Also due to the fact that both publishers and readers still have high hopes for its development. However, the professional systematisation of news about the e-books market is unlikely to be the case. The publication "Rynek książki w Polsce 2017", mentioned several times earlier, consists of five large volumes with a total volume of 2050 pages. Of course, you can also buy an electronic version. The whole publication devotes only a tiny subchapter to the issues of electronic content entitled "The world of bits" and placed in the volume entitled "Distribution", in "Direct sales". At this point

10 Some short studies has been devoted to e-books market after this date (e. g. Drapińska, A. Liberadzka, B. Trendy na ryknu książki w Polsce. Wybrane aspekty, 2017 or Zygierewicz, A. E-book. Product, technologia, rynek, 2013). However they report mostly data concerning economics of e-books market and its financial analysis.

11 Woblink, Nexto, Virtualo - internet bookstores. All three are pioneers on the Polish e-book market since 2008-2010.

12 "Biblioteka Analiz" is a biweekly magazine, founded by Łukasz Gołębiewski.

13 A short mention of electronic media appears in the 2017 issue, but it concerns the declining number of paper encyclopaedias and dictionaries that are losing the fight against Wikipedia or Google. 
one may risk the thesis that the layout of content in this important publication is a good reflection of the nature of the real book market in Poland ${ }^{14}$. The categories used by the authors of "Rynek książki w Polsce" to organize the content are very unclear to a researcher looking for specific information.

Among this state of things, the initiatives of individuals or commercial companies, which are trying to introduce a certain systematic approach to the growing market of electronic books, seem to be even more valuable.

The Virtualo company, the organizer of the nationwide campaign "Czytnikoliczenie" mentioned at the very beginning, runs not only its own Internet bookstore, but apart form it also tries to be as well a culture animator and promoter of e-readership ${ }^{15}$ in the spirit of the philosophy it adheres to. Now, let's say a few more words about the course of "Czytnikoliczenie". In order to encourage readers to take part in it, a promotional campaign was tailored: in exchange for filling in a questionnaire on the bookstore's website, the participants received a code enabling them to download the electronic book of the BURDA Media Publishing House and discount codes to be used in the ebooki.allegro.pl bookstore.

The results of the action were as follows: 5500 people took part in it. However, this is a very small number of the most involved users, who regularly visit online bookshops and follow promotions on e-books on various blogs and portals. The estimated number of users of e-readers, i. e. by default e-readers, is about 100,000 (Drózd, 2014).

\section{E-reading in Poland}

For the purpose of this article we will provide answers to two basic questions: 1) Since when have you been reading e-books? 2) What do you read on? (Drózd, 2014).

14 The five parts are: 1 . Publishing houses (Main trends on the publishing market; forecasts for the publishing market, publishing business in the world in 2016, ranking of publishing houses, largest book publishers in 2016); 2. Distribution (wholesale bookshop, retail bookshop, direct sale, import and export of books); 3. printing and paper (book printing houses, bookshop. Offset and digit - fight for the market, revolution in printing, book in the People's Republic of Poland 1945-1989, criteria for evaluating printing houses in the People's Republic of Poland until 1989 and the Republic of Poland after 1990, the history of Polish printing houses on the example of the printing house Dom Słowa Polskiego, ranking of "Magazyn Literacki Książki" book printing houses for 2017, printing houses in Poland, producers and distributors of printing machines and materials, paper and electronic media, cellulose, newsprint, wood-free papers, woodfree papers, coated wood-free papers, conversion of paper machines to cardboard production, American market, markets of developing countries, European market, Polish paper manufacturers, foreign paper manufacturers, paper distributors in Poland, appendix. Nanopapier what is such); 4. Fairs, Institutions, Media (Book Fairs, festivals, cultural institutions, organizations, foundations, higher education, awards, media, literary agencies), 5. Who is Who. A detailed table of contents has been deliberately quoted in its entirety to show the full range of topics. This makes it possible to find out which problems of the book market are taken into account and which are completely ignored.

15 Virtualo.pl. URL: https://virtualo.pl/o-nas/ (accessed 10.10.2019).
When asked, since when you have been reading ebooks, $2 \%$ declared that they had started reading ebooks before 2009. 4\% since 2010, 2011 $10 \%$, and from $2012-29 \%$, from $2013-39 \%$. $16 \%$ of respondents admitted starting reading e-books in 2014 (Drózd, 2014). It should be noted that the survey was conducted in the middle of 2014. This indicates very well the steadily growing trend at the turn of 2009-2014 in the number of people reading e-books. At the turn of 2011-2012 the increase was even threefold.

The answers given by the respondents to the second question "What do we read on" show that KINDLE is the most popular ebooks reading device. It is used by as much as $73 \%$ of all those participating in the survey. The second place was taken by the Onyx Book reader (5\%) and the third by the PocketBook (4\%). The rest reads on other brands or use an iPad, a tablet or a smartphone (Drózd, 2014).

The conclusions drawn by Virtualo after the end of the "Czytnikoliczenie" are as follows: "In the National Library's readership survey, the criterion for "real readers" was 7 and more books a year and only $11 \%$ of Poles read so many books a year. Meanwhile, research conducted by Virtualo shows that e-readers read on average 3 times more books than paper readers, who are mainly the subject of the National Library's research. Also interesting in this context are the data of the National Library, which shows that $7 \%$ of the respondents admitted to reading e-books and $6 \%$ to listening to an audiobook. It shows that although e-readers are a minority among all readers, they form an elite of people who read far more than the average"16. The above juxtaposition of the results of "Czytnikoliczenie" with the research of the National Library directs our attention to a very interesting phenomenon. E-readers make only $1 \%$ of the respondents, but this is a group that reads more than average. Among e-readers there are also many Internet users who lead a lively literary life on portals and blogs, commenting and recommending each other's readings. Virtual literary culture, created and developed by the participants themselves, where the reader is the author and the author is the reader, is already a global phenomenon and in this aspect of e-reading in Poland rivals other countries, where the general level of reading is much higher.

The problem of low level of reading is only one problem faced by publishers and sellers of e-books. The second important problem is the issue of content promotion. The President of Virtualo, Robert Rybski, says that "digital content must be sold in a different way and only a few of the strongest entities have the idea how to do it"16. Publishers, in cooperation with authors, are constantly looking for answers to the question of what is needed to

16 VIRTUALO. Ebooki, audiobooki, eprasa, darmowe książki. URL: https://virtualo.pl/?gclid=EAIaIQobChMIpquFsOC-5wIVwaSaCh0gmQvEEAAYASAAEgIaO_D_BwE (accessed 18.12.2019). 
effectively sell digital content. Are there any special conditions as far as Poland is concerned? How is it in other countries? In the context of the outlined situation of readers and reading in Poland, it seems that the biggest obstacle to the development of the e-books market is a small or total lack of interest from the potential buyers, i. e. a lack of readers. The second significant obstacle is the price of the e-book itself. As far as the group of those who actually read e-books is concerned, one of the weak points of the e-book market is still a rather narrow title offer of e-books compared to paper list.

Robert Drózd, the author of "Świat Czytników", thanks to his passion rightly recognized as an expert in the field of e-books, claims that the value of the e-book market is "several dozen million zlotys. This is still a drop in the ocean of paper sales. The e-book market has been growing significantly for several years, but there is no decisive impulse to go beyond this niche of a few per cent" $^{117}$. There is also a lack of accurate data on the number of new titles released in electronic form. This data is not even provided by the National Library, despite the creation of the Digital Repository. "Since 2009, the National Library has had a Repository for Electronic Documents, which collects monographs and serial publications, published only in digital form and available on the Internet. Electronic documents are sent voluntarily by publishers as a legal deposit. According to the Regulation of the Minister of Culture and Art of 6 March 1997 on the list of libraries entitled to receive legal deposit of particular types of publications and the rules of their storage, in Poland two libraries have the right to a legal deposit of electronic documents: The Jagiellonian Library and the National Library. For each publishing house applying to the Repository, a password-protected access account is created, to which the publishers hand over the publications themselves. The editors of the Repository correct the entered metadata of documents and anchance them if necessary. (...) In 2015, publishers submitted 50,243 publication units to the Repository (60,843 in 2014 and 55,948 in 2013)" (Gołębiewski, 2017). Unfortunately, access to these documents is possible only in the National Library. The National Library also does not maintain any separate catalogue for these documents and the main catalogue does not give additional information, how many of the bibliographic records concern e-books, etc.

Another aspect of this situation, where there is no complete and constantly upgraded database of e-publications, is that all groups interested in e-books - readers, publishers, librarians, researchers - do not really know how rich the offer of e-books in Poland is. "By the middle of 2014, almost 35,000 titles were available in digital form, and 20,000 after the exclusion of classics and non-commercial titles" (Wimmer, 2011). While the vast majority of new titles are currently available in electronic

17 VIRTUALO. Ebooki, audiobooki, eprasa, darmowe książki. URL: https://virtualo.pl/?gclid=EAIaIQobChMIpquFsOC-5wIVwaSaCh0gmQvEEAAYASAAEgIaO_D_BwE (accessed 18.12.2019). form, the number of e-books, which by 2010 - symbolically considered the beginning of the e-book market in Poland - did not have its digital version, is growing relatively slowly. This is almost the whole world of classical Polish and world's fiction, from Joyce to Marquez. According to Robert Rybski, this is one of the obstacles to the development of the market: "We are constantly looking for opportunities for growth in the e-book market to achieve three-digit results. We carefully analyse the sales structure with the use of business intelligence tools. The results indicate that one of the main restraints to the more dynamic development of the e-book market is still the poor availability of back-list titles ${ }^{18}$.

Fortunatelly, as the largest publishers and sellers of electronic books are - just like e-readers - people with passion, they continue their efforts to find new ways of promoting e-content. An event on a European scale, which had its place in Poland and contributed to the opening of the electronic books market, was the abolition of DRM protecion. In 2011, the Helion publishing house (Wimmer, 2011), publishing mainly IT books, decided to take this step. On their initiative, the ebookpoint.p ${ }^{19}$ electronic book sales platform was created, which to this day is doing well and is still expanding its ebooks offer.

Promotional solutions commonly used in the ebooks market are: sale of books in many formats (EBUP, MOBI, PDF), e-books in a package with soundtrack, which can be listened to while reading, e-books in sets with an audiobook, and finally an electronic and a paper version together. However, there are still some publishers who look at the electronic version of a book as a product that can bring losses rather than profits. This attitude is caused by fear of piracy. The Virtualo report reminds us of a book by a popular Polish fantasy novelist Andrzej Sapkowski. "From the very beginning, the publisher announced that the book would be published only in print, which caused great dissatisfaction among e-readers. Despite numerous phone calls and e-mails to the publishing house, only the printed version was present on the market. After some time someone scanned the paper version, threw into the Internet and ... here's how the e-book was ready. Eventually the publisher decided to make the official version of the e-book available, but the losses incurred by the publisher without listening to the voice of readers who wanted to buy a book in an electronic version legally are simply impossible to estimate ${ }^{20}$.

One of a very successful initiative of promoting e-books is an e-book database "Upoluj E-booka" 21. It gathers broad information about e-books that are currently in sale and, in case of interest, redirects the

18 VIRTUALO. Ebooki, audiobooki, eprasa, darmowe książki. URL: https://virtualo.pl/?gclid=EAIaIQobChMIpquFsOC-5wIVwaSaCh0gmQvEEAAYASAAEgIaO_D_BwE (accessed 18.12.2019).

19 Ebookpoint.pl. URL: https://ebookpoint.pl/ (accessed 18.12.2019).

20 VIRTUALO. Ebooki, audiobooki, eprasa, darmowe książki. URL: https://virtualo.pl/?gclid=EAIaIQobChMIpquFsOC-5wIVwaSaCh0gmQvEEAAYASAAEgIaO_D_BwE (accessed 18.12.2019).

${ }^{21}$ E-books hunt. URL: https://upolujebooka.pl/ (accessed 18.12.2019). 
customer to a bookstore, which offers the product. The database is oriented to search for the cheapest e-books, to save the readers' money and time. No wonder it has become very popular among its users.

The leitmotif of Łukasz Gołębiewski's book E-book. Broadband culture is that in a world dominated by modern technologies, one of the few possible ways for the legal culture to survive, legal culture, i. e. one that respects and recognizes copyright, is to create a model of acquiring e-books onto an e-reader available for a symbolic zloty and e-books available in a subscription (Gołębiewski, 2009). Legimi, another important online bookstore on the market, has gone in this direction. The campaign under the slogan "E-reader for one zloty" is being advertised by Agata Passent, a journalist, president of the Agnieszka Osiecka „Okularnicy” Foundation and a great book lover. The Legimi bookstore is doing quite well. There are two counters on their website: one indicating the number of minutes devoted to reading, the other the number of books downloaded. Legimi has also established cooperation with the Public Library of the Capital City of Warsaw. For the first 300 patrons with a valid library card, the library has prepared codes enabling them to $\log$ in to the Legimi service and have free access to 20,000 titles $^{22}$. This is indeed an impressive number. It is worth remembering, however, that this number of e-books very often includes works from the public domain, as well as contemporary books made available by authors on Creative Commons or in Open Access. Sadly, this is from time to time also the activity among major global aggregators selling e-books. This phenomenon is likely to disappear only when a full current catalogue of books published on the basis of Open Access will be established ${ }^{23}$.

Subscription services, such as Legimi, have globally turned out to be - at least for the time being a great disappointment. Magdalena Lemańska, a journalist from the "Rzeczpospolita" daily newspaper, points out the following: "At the end of 2015, one such service disappeared from the American market - Oyster, which operated on the same idea as Spotify or Netflix - for a fixed monthly fee it offered readers access to a huge amount of e-books. In the United States there are still platforms such as Amazon's Kindle Unlimited or Scribd, but according to PwC analysts, despite the affordable price (less than 10 dollars per month), they will have a weak market position until the publishers finally start to make current bestsellers available on them. The Kindle Unlimited catalogue does not include Harper Lee's

22 Koszykowa.pl. URL: http://www.koszykowa.pl/home/ komunikaty/4590-darmowy-dostep-do-18-000-ebookow-w serwisie-legimi-w-prezencie-od-biblioteki (accessed 18.12.2019).

23 The issue of Open Access, the popularity of this model among authors, is a secondary issue in this article. However, it is worth mentioning that many new, novice authors have taken advantage of the digital world and published their works electronically through selfpublishing and then posted them for free wherever possible.
"Go, Guard Attitude" (ed.), E. L. James' trilogy and none of the Harry Potter's series" (Lemańska, 2016).

Both examples - from the Polish and global markets - prove that it is not clear in what direction the electronic book market will develop. Much depends on the type of content. According to Magdalena Lemańska, "by 2020, revenues from the sale of all books will fall by several percent. Even more and more popular e-books will not help (Lemańska, 2016). Lemanska even predicts that "the entire book market (not only fiction, but also books for professionals and textbooks) will shrink by $3.05 \%$ to $\$ 667$ million by 2020 . At the same time, revenues from the sale of fiction will fall the most (by 7.2\%)" (Lemańska, 2016). These forecasts are taken from materials made available by $\mathrm{PwC}^{24}$ company, which publishes an annual report with forecasts for the media and entertainment market.

Włodzimierz Albin, President of the Polish Chamber of Books, is of the same opinion and agrees "that the decline in influence in the textbook segment may slowly slow down, as textbook producers have already undergone key changes in this market. However, the industry is not convinced of the forecasts for fiction. The situation on the fiction market is difficult to predict, because one international bestseller such as Harry Potter or 50 shades of Grey, that can completely change the situation, is enough (Lemańska, 2016).

According to the latest report by $\mathrm{PwC}$, a company researching the prospects for development of the entertainment and media sector in Poland, including a forecast for 2018-2022, the book market will grow by only $2.5 \%$. VR technology, which is in the first place, will grow by as much as $40 \%^{25}$. The forecast presented by $\mathrm{PwC}$ in 2016, which is unfavourable for books, both in paper and electronic form, is, interestingly enough, at the moment the latest forecast for books. Besides, the phrase "books" does not appear there at all. On the other hand, we have the phrase "press and publishing houses". Books as a separate category of media are not taken into account. The forecast for 2017-2021 does not mention this medium at all, and the latest forecast for 2018-2022 is a 16-page material, half the "thinner" than the forecast for 2017-2021, and the books are mentioned only in the infographics showing the growth forecast of the role of particular media. The book (as medium) is located at the bottom of the chart and unbeatably loses to such media as advertising, OTT or VT, which this year is in the first place. Virtual entertainment provided for a fee definitely wins over a book that requires the involvement of imagination. The report also shows one interesting observation that all media

${ }^{24}$ Pw C.pl. URL: https://www.pwc.pl/ (accessed 27.12.2019).

5 PwC: wzrost, bezpeczeństwo, efektywność. URL: https://www. pwc.pl (accessed 11.01.2019). 
based on advanced technology are in danger of falling into their own trap. What is the trap? Let's show it with the example of VR media. „VR is in the situation of 'hens and eggs'. Without mass access to lowcost devices, content producers will not invest in new formats, without a large selection of interesting content, consumers will not be able to buy devices in crowds, and accessory suppliers, unable to build a mass scale of sales, will not be able to reduce equipment prices" ${ }^{25}$. The same is true for e-books and e-readers: without a reader available for one PLN and without the number of electronic publications, similar to the number of printed publications, e-reading will never develop on a mass scale. It remains to be hoped that the subscription solution adopted by Legimi bookstore will be accepted for good on the Polish market. Several models of e-readers (three models of PocketBook and three inkBook) are already available in the offer, which certainly makes the bookstore's offer more attractive.

Let's go back to the e-reader for a moment. Employees of Virtualo, an online bookshop responsible for creating a report giving the most complete picture of the e-books market in Poland so far, state that the largest group of recipients of e-books are young people. "Most e-books are read by young people aged 24 to 45 . We also see a growing interest among the youngest people, i. e. 18+, who very often read e-books on smartphones. We would also like to interest the oldest people in e-books, especially as the reader has the option to enlarge the font" says Martyna Bednarczyk, coordinator for marketing at Virtualo (Bednarczyk, 2017). On the electronic books market there is also an increase in the number of publications intended for the youngest readers. Electronic books for children and young people are in the offer of publishing houses that traditionally specialize in children's and youth literature (e. g. Nasza Księgarnia, Wilga), as well as those that occasionally publish children's literature (e. g. PWN). Currently, the offer of e-books for children and teenagers is best visible in online bookstores, where you can easily find the category of books you need. On the pages of the bookstores themselves, the information about publishing an electronic version is often hidden quite deeply. Perhaps the fact that Virtualo sees in the young reader

\section{References}

Bednarczyk M (2017) Obniżona stawka VAT może zwiększyć sprzedaż e-booków. Prawo.pl. URL: https:// www.prawo.pl/podatki/obnizona-stawka-vatmoze-zwiekszyc-sprzedaz-e-bookow,23918.html (accessed 27.12.2019).

Dawidowicz-Chymkowska O (2018) Ruch wydawniczy w Liczbach 2017. Ksiązki. Biblioteka Narodowa. Raporty $B N$. URL: https://bn.org.pl/projekty/raporty-bn/ruch- as the most frequent recipient of e-books is the first signal that something has changed positively in terms of the level of readership in Poland.

Bednarczyk's statement appears in the context of abolishing the $23 \%$ VAT rate on e-books, which so far has effectively blocked its development. The year 2018 brought good news to publishers and readers alike, which may become a new impulse, pushing the e-books market to a higher level. In September 2018, the European Union positively accepted the proposal to equalise VAT rates for paper and electronic books (Nawotka, 2018). The rates in force in Poland - 5\% for paper books and $23 \%$ for e-books respectively - are very diverse and are among the highest in Europe. The Ministry of Finance has announced that lower rates are likely to come into force as early as January 2019. "This will have a positive impact on the development of the book and publication market, including research and development, increase the legal stock of digital books and prevent the development of Internet piracy. The Ministry of Finance wants to present as soon as possible a proposal for changes, which will assume a reduction in VAT rates for electronic publications. I hope that this much needed and beneficial solution will enter into force as soon as possible, already at the beginning of 2019". This is what Minister Teresa Czerwińska says (Musiał, 2018).

\section{Conclusion}

The report created after the "Czytnikoliczenie" campaign, quoted so often, gave us quite a full picture of the Polish e-books market. When the next report will appear, we do not know. It remains to be hoped that in the light of the planned changes in e-book fees and with the unflagging share of e-book fans and lovers, who contribute to the development of this product and medium, it will bring new, surprising and satisfactory data on the development of the e-book market.

Thus, the review of the modern electronic market of Poland permits to assert that all its main segments continue to develop. Data of social interrogations testify to widening of e-books readers' audience, users of e-reading devices being its core.

wydawniczy-w-liczbach/ruch-wydawniczy-w-liczbach2017-k (accessed 10.10.2019).

Drózd R (2014) Ruszyło Czytnikoliczenie - „Pokażmy ilu nas jest!” + gratisy: e-book i kod. Świat Czytników. Wszystko o czytnikach e-booków, książkach elektronicznych i Kindle w Polsce. URL: https:// swiatczytnikow.pl/ruszylo-czytnikoliczeniepokazmy-ilu-nas-jest-gratisy/ (accessed 07.09.2019).

Gołębiewski Ł (2008) Śmierć książki. No future book. Warszawa. $145 \mathrm{~s}$. 
Gołębiewski Ł (2009) Eksiążka/book. Szerokopasmowa kultura. Warszawa. $132 \mathrm{~s}$.

Gołębiewski $Ł$ (2012) Gdzie jest czytelnik? Warszawa. 190 s.

Gołębiewski Ł (red) (2017) Rynek Książki w Polsce 2017. W 3 ks. Warszawa.

Gołębiewski Ł and Waszczyk P (2012) Rynek książki w Polsce 2012. Warszawa. 889 s.

Koryś I, Michalak D, Zasacka Z and Chymkowski R (2018) Stan czytelnictwa w Polsce w 2017 roku. Warszawa: Bibl. Narodowa. $187 \mathrm{~s}$.

Lemańska M (2016) Wpływy ze sprzedaży książek w Polsce coraz niższe. Nie pomogą coraz popularniejsze e-booki. Rzeczpospolita. URL: https://www.rp.pl/ Media-i-internet/309269872-Wplywy-ze-sprzedazyksiazek-w-Polsce-coraz-nizsze-Nie-pomoga-corazpopularniejsze-e-booki.html (accessed 27.12.2019).

Mendruń R (2018) Rynek książki po Polsku. RynekKsiazki - Największa baza materiałów w branży. URL: https://rynek-ksiazki.pl/czasopisma/rynekksiazki-po-polsku/ (accessed 05.10.2019).
Musiał M (2018) Obniżona stawka VAT na publikacje elektroniczne od 2019 r. IFOR. Księgowość firm. URL: https://ksiegowosc.infor.pl/podatki/vat/stawkivat/2759912,Obnizona-stawka-VAT-na-publikacjeelektroniczne-od-2019-r.html (accessed 23.14.2019).

Nawotka E (2018) Europeans approve flexible VAT for ebooks. Publishers Weekly. URL: https://www.publishersweekly. $\mathrm{com} / \mathrm{pw} /$ by-topic/international/international-booknews/article/78199-europeans-approve-flexible-vatfor-e-books.html (accessed 14.05.2019).

The world of e-readers. Wszystko o czytnikach e-booków, ksiązkach elektronicznych $i$ Kindle $w$ Polsce. URL: https://ebooki.swiatczytnikow.pl/szukaj/The\%20 world\%20of\%20e-readers (accessed 07.09.2019).

Wimmer P (2011) Ebooki - czy to koniec DRM? PCWorld. URL: https://www.pcworld.pl/news/Ebooki-czy-tokoniec-DRM,376823.html (accessed 18.12.2019). 